\title{
EFFECT OF INTRAPARTICLE MASS TRANSFER RESISTANCE ON REACTIVITY OF IMMOBILIZED YEAST CELLS
}

\author{
SHINTARO FURUSAKI AND MINORU SEKI \\ Department of Chemical Engineering, University of Tokyo, Tokyo 113
}

Key Words: Biochemical Engineering, Chemical Reaction, Diffusion Resistance, Immobilized Yeast,
Reaction Rate, Ethanol Production, Ca-Alginate Gel

Effect of diffusion resistance on reaction by using an immobilized yeast entrapped by Ca-alginate gel was studied. Intraparticle effective diffusivity of substrate, $D_{e}$, depends upon cell density, $c_{c}$, i.e. $D_{e} / D_{0}=k_{2}\left(1-k_{1} c_{c}\right)^{2}$. Here, $D_{0}$ is a reference diffusivity, e.g. diffusivity in water; $k_{1}$ and $k_{2}$ are constants. Overall reaction rates of ethanol production by immobilized resting-yeast were measured. Experimental rates coincide well with calculated results using the effective diffusivity and reaction rate of free cells. Diffusion seemed to be restricted by cells. Thus large cell density does not necessarily mean high reactivity. Finally, the curvature of the Lineweaver-Burk plot is pointed out.

\section{Introduction}

Immobilized microorganisms have been used to produce useful materials, and extensive studies in this field are being carried out. Reaction rates of immobilized bio-catalyst have mostly been studied on the basis of applying the Lineweaver-Burk (L-B) plot, ${ }^{10.18)}$ originally obtained for native enzyme reactions. However, it was recognized that these apparent L-B plots turned out to become curved lines due to mass transfer resistances. ${ }^{5,6,9,15,17,24)}$ Thus, linearized apparent L-B plots, widely adapted, may give different values for $K_{m}$ and the maximum reaction rate, $V_{\max }$, according to the range of substrate concentration and the weight applied to each experimental parameter.

Immobilized yeast has been extensively studied, ${ }^{1,13,22,26)}$ especially for production of ethanol from various biomass materials. However, most studies have been carried out by superficial treatment, the salient effect of intraparticle diffusion not being considered. This paper aims at an evaluation of the effect of diffusional resistance on the overall kinetics of immobilized-cell fermentation. The curvature of the L-B plot is also discussed in the course of analysis. Ethanol fermentation using Saccharomyces cerevisiae was chosen as the model reaction for this study.

\section{Experimental}

\subsection{Materials and methods}

Saccharomyces cerevisiae was kindly supplied by

Received February 9, 1985. Correspondence concerning this article should be addressed to S. Furusaki. M. Seki is now with Mitsubishi Chemical Industries, Lid., Yokohama 227
Oriental Yeast Co., Ltd. The yeast was cultivated at $303 \mathrm{~K}$, using the medium shown in Table 1. Starting solution was prepared by adding $10 \mathrm{ml}$ of the initial solution, which contains $30 \mathrm{~g}$ of the original wet-cell in $1 l$ of water, to $300 \mathrm{~m} l$ of the medium. The sample cells were collected by centrifuging the cultivated solution of the final stage of the logarithmic growth period (8-8.5 h of cultivation). A more detailed description is given elsewhere. ${ }^{23)}$

The immobilized yeast particles were prepared in the following manner: (1) sodium alginate was dissolved in water $(0.5-1.5 \mathrm{wt} \%)$; (2) yeast cells were mixed with the chilled Na-alginate solution (50$170 \mathrm{~kg}$ wet-cell $/ \mathrm{m}^{3}$ ); and (3) this yeast solution was dripped into chilled $1 \mathrm{M}-\mathrm{CaCl}_{2}$ solution. Particle diameter obtained was between 2 and $3.3 \mathrm{~mm}$, and was measured for every experiment. The diameter distribution was small, i.e. within $\pm 0.1 \mathrm{~mm}$. Reaction rates using the immobilized yeast were measured by the same continuous stirred-tank reactor described in the previous paper. ${ }^{7)}$ Cell population in the particles was obtained from the weight of cells. This could be carried out by first dissolving gel in $10 \% \mathrm{Na}$ polyphosphate solution and then collecting cell particles. Glucose concentration was determined by the Glucostat method and ethanol concentration by gas chromatography, Shimadzu 3BF, with a FID detector.

Diffusion coefficient of glucose substrate in the cellholding gel was measured in the following way. Xylose was chosen as a diffusing material because it was not metabolized by the yeast. This was confirmed experimentally by the fact that the cell population did not change after $3 \mathrm{~h}$ in xylose solution. Thus the diffusion of glucose was simulated by the diffusion of 
Table 1. Composition of culture medium of native yeast

$\begin{array}{lr}\text { Glucose } & 40 \mathrm{~kg} \\ \text { Polypeptone } & 10 \mathrm{~kg} \\ \text { Yeast extract } & 5 \mathrm{~kg} \\ \mathrm{KH}_{2} \mathrm{PO}_{4} & 5 \mathrm{~kg} \\ \mathrm{MgSO}_{4} \cdot 7 \mathrm{H}_{2} \mathrm{O} & 2 \mathrm{~kg} \\ \text { Water } & 1 \mathrm{~m}^{3}\end{array}$

xylose in a system containing active cells. The rate of diffusion was measured by the unsteady method, ${ }^{3}$ ) keeping the concentration in the outer solution negligibly small. ${ }^{12)}$ Before measurement the particles were put in equilibrium with an aqueous solution of $10 \%$ xylose, $1 \%$ glucose and $0.05 \mathrm{M} \mathrm{CaCl}_{2}$. From this, the distribution coefficient of xylose between gel and liquid phases was found to be 0.99 . From the rate of elution of xylose the diffusion coefficient can be calculated. ${ }^{3,12)}$ Here, the concentration of xylose was determined by the Bial method. ${ }^{4)}$

The reaction rate by free cells was obtained from batch fermentation. The medium was prepared by dissolving glucose $1-100 \mathrm{~g}, \quad \mathrm{MgSO}_{4} \cdot 7 \mathrm{H}_{2} \mathrm{O} \quad 0.5 \mathrm{~g}$, $\mathrm{KH}_{2} \mathrm{PO}_{4} 1.0 \mathrm{~g}$ and $\mathrm{CaCl}_{2} \cdot 2 \mathrm{H}_{2} \mathrm{O} 7.35 \mathrm{~g}$ in $1 l$ of water. The cells collected in the manner stated above were kept in sterilized water at $278 \mathrm{~K}$ for ca. $12 \mathrm{~h}$. Before measurement the cell solution was warmed up to $303 \mathrm{~K}$ and left for $2 \mathrm{~h}$. Therefore, the cells in the experiment were mostly in the state of the induction period of growth. The fermentation rate of the cells thus prepared was assumed to be about the same as that of immobilized cells under identical reaction conditions. The concentration of yeast cells did not change within the first $2 \mathrm{~h}$ of fermentation.

The rate was determined from the initial change of ethanol concentration. First, the dependence upon glucose concentration was investigated by changing $S$ from $1 \mathrm{~kg} / \mathrm{m}^{3}$ to $100 \mathrm{~kg} / \mathrm{m}^{3}$. Next, ethanol inhibition was investigated by changing the ethanol concentration from 30 to $90 \mathrm{~kg} / \mathrm{m}^{3}$ while the glucose concentration was fixed at $100 \mathrm{~kg} / \mathrm{m}^{3}$.

\subsection{Diffusion in gel particles}

Diffusion coefficients in gel particles have been investigated by Nakanishi et al. ${ }^{21)}$ and Tanaka et al. ${ }^{25}$ ) Nakanishi et al. ${ }^{21)}$ stated that the diffusion coefficient depended on concentration of gelling agent (abbreviated as the gel concentration) for the case of polyacrylamide and dextran gels. For the particles holding active microbial cells, diffusion will occur through the space between the cells. This situation can be imitated by diffusing materials which the microbes do not ingest, and xylose was used as such a diffusing material.

First, diffusivity in the Ca-alginate gel was measured without introducing cells into it. The results are shown in Fig. 1. The concentration of Ca-alginate in the gel was changed from $2.27 \%$ to $4.57 \%$. No

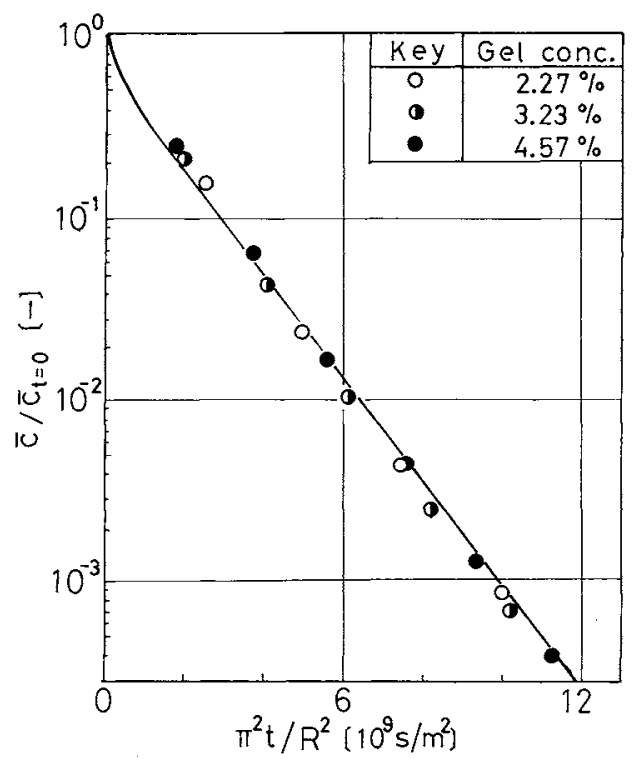

Fig. 1. Diffusion inside particles without cells. Gel concentration varies.

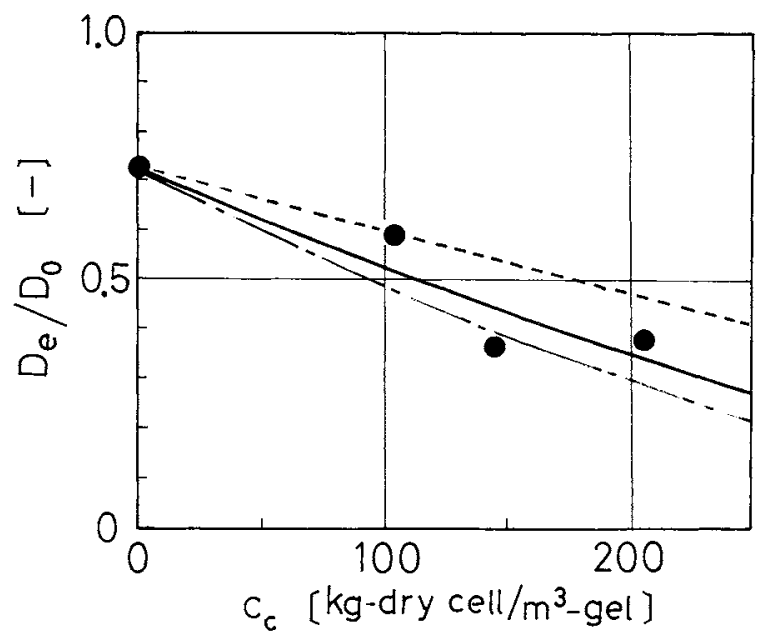

Fig. 2. Effective diffusivity with respect to cell density in gel.

dependency on gel concentration was seen from the experimental results. This is different from the results of Nakanishi et al. ${ }^{21)}$ In the case of immobilized cell systems the gel concentration could not be made large since the solution with the cell-mass became viscous and the gelled particles became too hard. Therefore, the range of gel-concentration change was small. Thus the dependency seemed to disappear. Finally, the effective diffusivity of xylose in the gel at $303 \mathrm{~K}$ was found to be $6.4 \times 10^{-10} \mathrm{~m}^{2} / \mathrm{s}$.

Next, dependency on cell concentration in the gel (i.e. cell density) was investigated. The cell density was changed from 108 to $205 \mathrm{~kg}$ dry cell $/ \mathrm{m}^{3}$. The results are shown in Fig. 2. It was found that the diffusivity became small for large cell density, e.g. $205 \mathrm{~kg}$ dry $\mathrm{cell} / \mathrm{m}^{3}$. The obtained values of diffusivity were compared with diffusivity in water calculated by use of the 


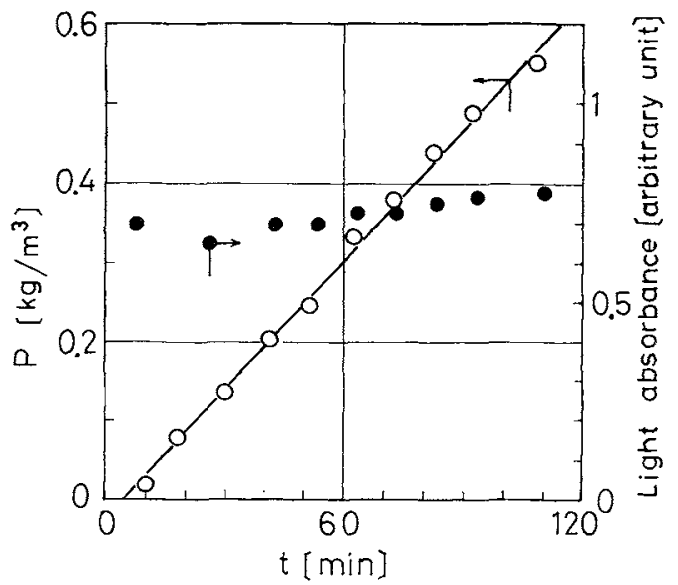

Fig. 3. Initial rate study using free cell.

Wilke-Chang equation. ${ }^{28)}$ This equation estimates the diffusivity of glucose within $5 \%$ of the experimental value. So it was used for estimation of the xylose diffusivity in water, $D_{0}$, i.e. $8.79 \times 10^{-10} \mathrm{~m}^{2} / \mathrm{s}$ at $303 \mathrm{~K}$. The ratio of effective diffusivity, $D_{e}$, to $D_{0}$ was finally correlated by the cell density in gel particles, $c_{c}$. Thus,

$$
\frac{D_{e}}{D_{0}}=k_{2}\left(1-k_{1} c_{c}\right)^{2}
$$

Equation (1) was introduced by using the randompore model, ${ }^{27)} D_{e} / D_{0}=k_{2} \varepsilon^{2}$, assuming that the void fraction, $\varepsilon$, is proportional to the volume fraction unoccupied by cells in the gel. From values of the experimental data in Fig. 2, the values of $k_{1}$ and $k_{2}$ were determined as $1.542 \times 10^{-3} / / \mathrm{g}$-dry cell and 0.728 , respectively. The chain line in Fig. 2 shows the calculated result of the random-pore model assuming that $\varepsilon$ is equal to the fraction of gel volume unoccupied by cells. The difference of the two lines is small. Therefore, the random-pore model was found to hold true in our case. For comparison the broken line shows the result for $D_{e} / D_{0}=k_{2} \varepsilon$, where the value of $\varepsilon$ was similarly calculated. On the other hand, Klein and Manecke ${ }^{14)}$ used exponentially decreasing diffusivity with the cell density. More data are needed to discuss the adequacy of these two kinds of correlations. The above correlation, Eq. (1), will be used in a correlation described later.

\subsection{Ethanol fermentation rate of native yeast}

Reaction rate using native yeast, i.e. free cells, was studied with respect to dependence on substrate concentration and ethanol inhibition. An example of initial progress of fermentation is shown in Fig. 3 . From the slope of the solid line the reaction rate can be obtained. Light absorbance in the medium changed slightly, as shown in the figure, but counting by the use of the Burker-Turk cell-counting plate revealed an almost constant number of cells. The $\mathrm{pH}$ value was initially $3.9-4.0$, but decreased

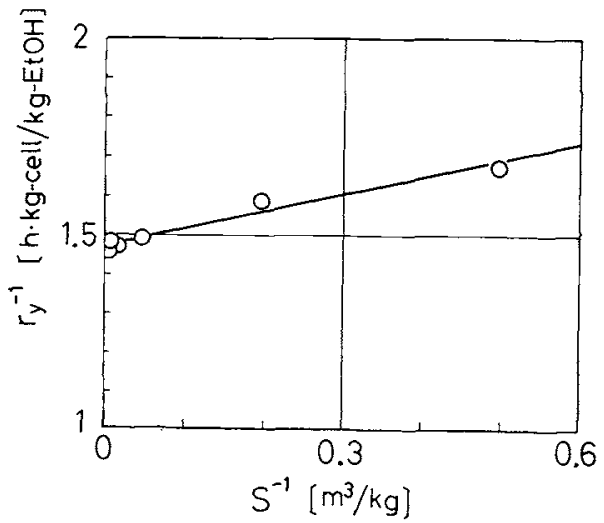

(a)

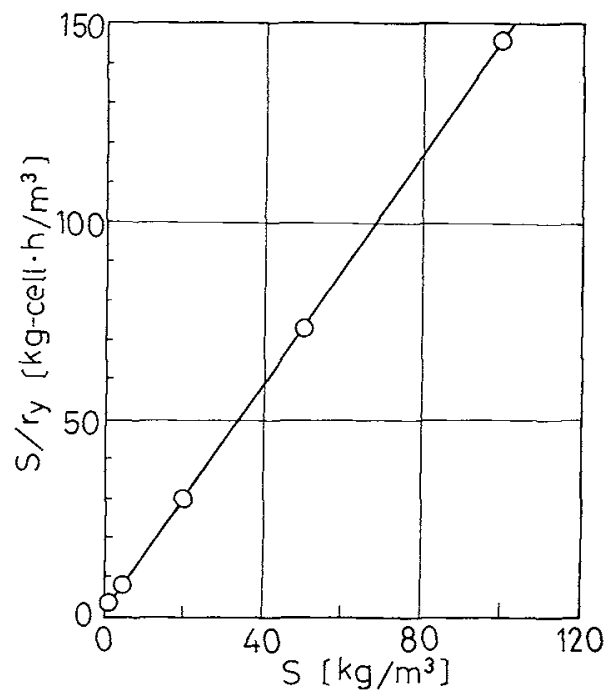

(b)

Fig. 4. Reaction rate of free cell. Dependence on glucose concentration. (a) L-B plot; (b) plot for large glucose concentrations.

by 0.20 .3 during the course of fermentation. Dependency on substrate concentration is shown in Fig. 4. Even slight contamination by miscellaneous microorganisms seemed to decrease the reaction rate. This gave some scatter of experimental points. So, the data representing the maximum rate at each substrate concentration were selected for correlation, as shown in Fig. 4. From the figure it is found that the Michaelis-Menten kinetics, Eq. (2), can be applied and the values of $V_{\max }$ and $K_{m}$ are obtained as 0.678 $\mathrm{kg}-\mathrm{EtOH} / \mathrm{h} \cdot \mathrm{kg}$-dry cell and $0.229 \mathrm{~g} / \mathrm{l}\left(1.27 \mathrm{~mol} / \mathrm{m}^{3}\right)$, respectively.

$$
r_{y}=\frac{V_{\max } S}{K_{m}+S}
$$

Nagatani et al. ${ }^{20)}$ reported the following values of $V_{\max }$ and $K_{m}$ for S. cerevisiae: $V_{\max }=1.0 \mathrm{~h}^{-1}$ and $K_{m}=$ $0.44 \mathrm{~g} /$ l. Chibata ${ }^{2)}$ reported $V_{\max }=0.90-0.87 \mathrm{~h}^{-1}$. Considering the difference in microbial strains and the difference in fermentation conditions, these differences in rate constants seem to be reasonable. The 


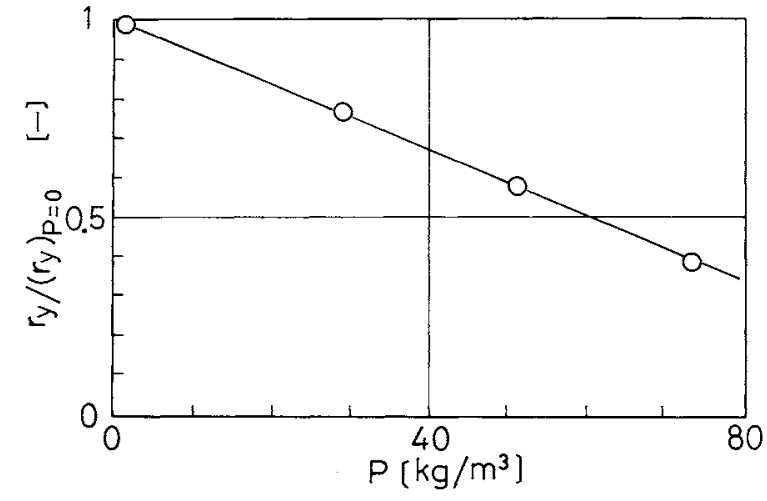

Fig. 5. Ethanol inhibition. Reaction rate of free cell.

value of $V_{\max }$ changes with the pretreatment of yeast. It was $0.554 \mathrm{~kg}-\mathrm{EtOH} / \mathrm{h} \cdot \mathrm{kg}$-dry cell for the yeast strain used for immobilization. So, this $V_{\max }$ will be used in later analysis.

Ethanol inhibition was measured by adding ethanol to the initial medium. The extent of reaction was measured by the decrease of glucose. After calculation of the reaction rate Fig. 5 was prepared similarly to the previous study. ${ }^{7)}$ Thus, the final form of the freecell reaction rate is given by the following equation, where $a=8.40 \times 10^{-3} \mathrm{~m}^{3} / \mathrm{kg}$ and other factors are given above.

$$
r_{y}=\frac{V_{\max } S}{K_{m}+S}(1-a P)
$$

Ghose and Tyagi ${ }^{8)}$ were the first to propose linear inhibition, modifying the correlation by Holzberg et al. ${ }^{11)}$ Their value for the constant $a$ was $8.77 \times$ $10^{-3} \mathrm{~m}^{3} / \mathrm{kg}$ for $S$. cerevisiae, which is close to our result.

\subsection{Reaction of immobilized yeast}

Immobilized yeast pellets were prepared by the method described above. By dissolving the gel and counting the number of surviving yeast cells by use of the methylene-blue method, more than $99 \%$ of the yeast cells were found to be alive. The reaction medium is given in Table 2. The reaction rates for the immobilized resting yeast are shown by points of the L-B plot in Fig. 6. The agitator in the reactor was rotated at $225 \mathrm{rpm}$. Changing this rate to $150 \mathrm{rpm}$ did not result in any change in fermentation rate. Therefore, film mass transfer resistance outside the particles was considered negligible. Solid lines in Fig. 6 are the calculated lines, which will be discussed in the following section.

\section{Discussion}

The L-B plot in Fig. 6 has interesting features. First, the values of $V_{\max }, 0.538 \mathrm{~kg}-\mathrm{EtOH} / \mathrm{h} \cdot \mathrm{kg}$-dry cell for a cell concentration of $178.3 \mathrm{~g} / \mathrm{l}$ is nearly identical with that of the free cells, $0.554 \mathrm{~kg}-\mathrm{EtOH} / \mathrm{h} \cdot \mathrm{kg}$-dry
Table 2. Composition of reaction medium for immobilized yeast

\begin{tabular}{lcc}
\hline Glucose & 100 & $\mathrm{~kg}$ \\
$\mathrm{MgSO}_{4} \cdot 7 \mathrm{H}_{2} \mathrm{O}$ & $0.5 \mathrm{~kg}$ \\
$\mathrm{KH}_{2} \mathrm{PO}_{4}$ & $1 \mathrm{~kg}$ \\
$\mathrm{CaCl}_{2} \cdot 2 \mathrm{H}_{2} \mathrm{O}$ & $7.35 \mathrm{~kg}$ \\
Water & $1 \quad \mathrm{~m}^{3}$ \\
\hline
\end{tabular}

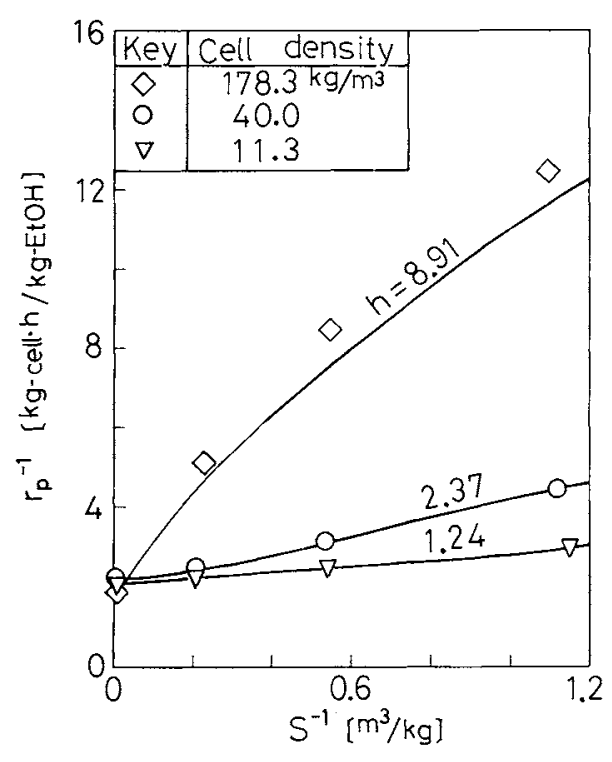

Fig. 6. Reaction rate of immobilized resting yeast.

cell. For the case of large cell density, the immobilized yeast seems to be as active as free cells. For smaller cell density, its activity is smaller than that of free cells. This might be an effect of some inactivation by the gel structure. Second, the apparent $K_{m}$ value becomes large for large cell density. This is probably due to the effect of intraparticle mass transfer resistance by the cell-body.

A more precise analysis can be made by use of data of effective intraparticle diffusivity and reaction rate of the free cell described above.

If the substrate is assumed to diffuse through the space in the gel unoccupied by cells, and diffusion inside the cell-body is assumed to be much faster than reaction, the situation can be imitated by the randompore model with reaction occurring at the pore wall. Thus the theoretical treatment for heterogeneous catalyst can be applied to the immobilized cell system as well. Then, the overall rate of reaction can be calculated by using the method of Kobayashi et $a l .{ }^{16,19)}$ A detailed procedure for carrying out the calculation is given elsewhere. ${ }^{6,23)}$ Calculations were carried out for the initial rate, where ethanol inhibition could be neglected. The solid lines in Fig. 6 show the results thus calculated. The coincidence with experimental data is satisfactory.

The L-B plots show curvature due to intraparticle diffusion resistance. Thus treatment by drawing linear 
L-B plots will give an approximate analysis only. This curvature will become larger for the case of immobilized cells when the cell density is large. Very large cell density may result in smaller overall reaction rate, due to the mass transfer limitation. ${ }^{14)}$

\section{Conclusion}

Reaction behavior of the immobilized cell was studied by the use of Saccharomyces cerevisiae immobilized by $\mathrm{Ca}$-alginate gel. Intraparticle diffusivity, which was independent of gel concentration, was correlated with cell density by Eq. (1), which was applied from analogy to random pore diffusion. The reaction rate using free cells was also measured and expressed by a Michaelis-Menten type rate equation with linear ethanol inhibition. The overall reaction rate for immobilized resting yeast was investigated and its behavior was explained by theoretical calculations using the intraparticle diffusivity and the freecell reaction rate. Finally, the inadequacy of using the linear Lineweaver-Burk plot is pointed out.

\section{Acknowledgment}

The authors express their thanks to Oriental Yeast Co., Ltd. for supplying the yeast for this study, and to the Iwatani Naoji Foundation for financial support.

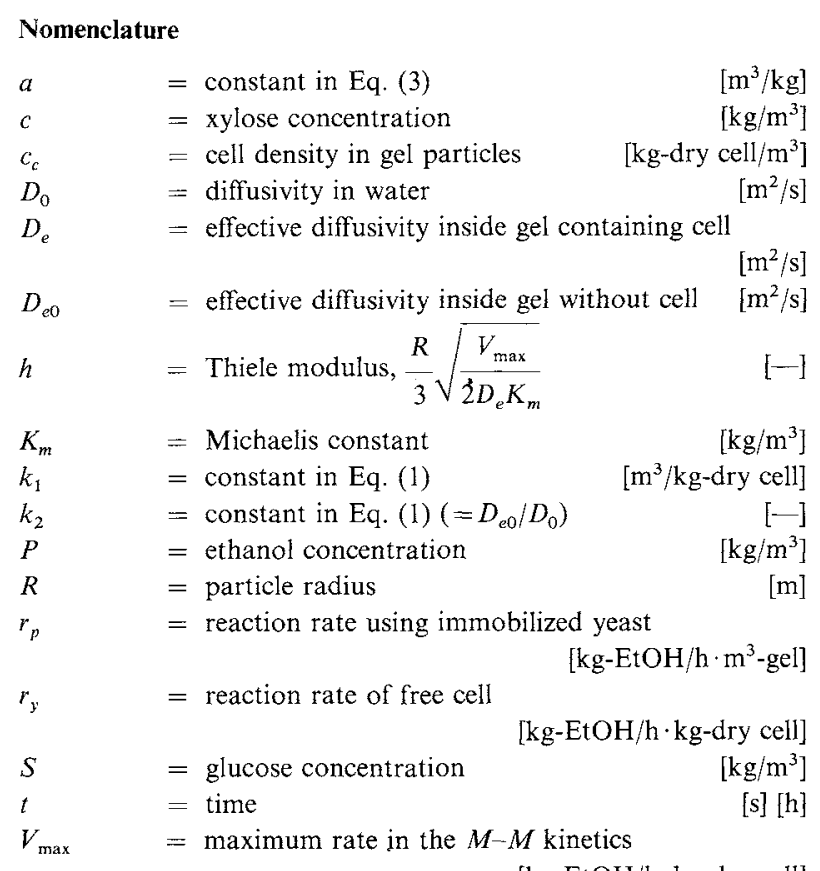

[kg-EtOH/h $\cdot \mathrm{kg}$-dry cell]

$\varepsilon \quad=$ void fraction in the random-pore model $\quad[-]$

\section{Literature Cited}

1) Bandyopadhyay, K. K. and T. K. Ghose: Biotechnol. Bioeng., 24, 781 (1982).

2) Chibata, I.: Kemikaru Enjiniaringu (in Japanese), 24(11), 1 (1979).

3) Crank, J.: "The Mathematics of Diffusion," 2nd ed., p. 90, Clarendon Press, Oxford (1975).

4) Fukui, S.: "Quantitative Analysis of Reducing Saccharides" (in Japanese), p. 85, Gakkai Shuppan Center, Tokyo (1969).

5) Furusaki, S. and N. Asai: Biotechnol. Bioeng., 25, 2209 (1983).

6) Furusaki, S., Y. Okamura and T. Miyauchi: J. Chem. Eng. Japan, 15, 148 (1982).

7) Furusaki, S., M. Seki and K. Fukumura: Biotechnol. Bioeng., 25, 2921 (1983).

8) Ghose, T. K. and R. D. Tyagi: Biotechnol. Bioeng., 21, 1401 (1979).

9) Gondo, S., S. Isayama and K. Kusunoki: Biotechnol. Bioeng., 17, 423 (1975).

10) Haldane, J. B. S. and K. G. Stern: "Allgemeine Chemie der Enzyme," p. 119, Steinkopt, Dresden (1932).

11) Holzberg, I., R. K. Finn and K. H. Steinkaus: Biotechnol. Bioeng., 9, 413 (1967).

12) Horowitz, S. B. and I. R. Fenichel: J. Phys. Chem., 68, 3378 (1964).

13) Kierstan, M. and C. Bucke: Biotechnol. Bioeng., 19, 387 (1977).

14) Klein, J. and G. Manecke: “Enzyme Engineering," I. Chibata, S. Fukui and L. B. Wingard, eds., Vol. 6, p. 181, Plenum Press, New York (1982).

15) Kobayashi, T. and M. Moo-Young: Biotechnol. Bioeng., 15, 47 (1973).

16) Kobayashi, T., K. Ohmiya and S. Shimizu: J. Ferment. Technol., 54, 260 (1976).

17) Lilly, M. D., W. E. Hornby and E. M. Cooke: Biochem. J., 100, 718 (1966).

18) Lineweaver, H. and D. Burk: J. Am. Chem. Soc., 56, 658 (1934).

19) Moo-Young, M. and T. Kobayashi: Can. J. Chem. Eng., 50, 162 (1972).

20) Nagatani, M., M. Shoda and S. Aiba: J. Ferment. Technol,, 46, 241 (1968).

21) Nakanishi, K., S. Adachi, S. Yamamoto, R. Matsuno, A. Tanaka and T. Kamikubo: Agric. Biol. Chem., 41, 2455 (1977).

22) Noguchi, S., M. Nagashima and M. Azuma: Pan-Pacific Synfuels Conf., Vol. 2, p. 464 (1982).

23) Seki, M.: M. S. Thesis, University of Tokyo (1984).

24) Silman, I. H. and E. Katchalski: Ann. Rev. Biochem., 35, 873 (1966).

25) Tanaka, H., M. Matsumura and I. A. Veliky: Biotechnol. Bioeng., 26, 53 (1984).

26) Tyagi, R. D. and T. K. Ghose: Biotechnol. Bioeng., 24, 781 (1982).

27) Wakao, N. and J. M. Smith: Chem. Eng. Sci., 17, 825 (1962).

28) Wilke, C. R. and P. Chang: AIChE J., 1, 264 (1955).

(Presented at the 18th Autumn Meeting of the Society of Chemical Engineers, Japan, at Fukuoka, October 1984.) 